\title{
Religious tolerance among college students: How it's influenced by religious orientation and personality traits?
}

\author{
Abdul Muhid \\ Faculty of Psychology and Health, UIN Sunan Ampel, Indonesia \\ abdulmuhid@uinsby.ac.id
}

\section{ARTICLE INFO}

Article history

Received 8 January 2019

Revised 9 January 2020

Accepted 25 February 2020

Keywords

big five personality

religious orientation

religious tolerance

\begin{abstract}
Religious tolerance among college students needs to be maintained to create harmonious conditions and peace among the religious community. This study aimed to explore the influence of religious orientations and personality traits on religious tolerance among college students. This study used a quantitative approach and performed a survey method that utilized three measurement tools of psychological scales: the Religious Orientation Scale-Revised, the Personality Scale of Big Five Personality and the Scale of Religious Tolerance. The subjects of this study were 280 students from six universities in Surabaya. The results of the study show that, there is a significant influence of religious orientation and personality traits on religious tolerance among college students. Partially, intrinsic religious orientation has a positive influence on religious tolerance, and on the contrary, the extrinsic religious orientation has a negative influence on religious tolerance. Of the personality traits (Big Five Personality), agreeableness and openness have a positive influence on religious tolerance. Meanwhile, extroversion, conscientiousness, and neuroticism do not have a significant influence on religious tolerance. Therefore intrinsic religious orientation and two personality traits agreeableness and openness - are important to develop religious tolerance among college students. While college student who have extrinsic religious orientation tend to have low religious tolerance.
\end{abstract}

\section{Introduction}

Indonesia has a huge diversity of ethnicities, religions, languages, and cultures. However, the diversity may become a threat if it is not fostered and used as social capital to build the integrity of the Republic of Indonesia (NKRI). The emergence of various horizontal conflicts lately shows that Indonesian's diversity is being threatened. Actually, religious diversity can be a positive energy in actualizing and maintaining tolerance among religious people (Handayani, 2010). According to Byrne (2011), religious tolerance may existence in a pluralistic state as long as the religious adherents can put forward the forms of pluralism and respect for differences.

A study on college student religious tolerance was conducted by Research and Development Agency and Training of the Ministry of Religion of the Republic of Indonesia. This study found personality, organizational involvement, learning outcomes of religious education, and educational environment have impact on religious tolerance (Bahari, 2010). Other study showed that nowadays, students had been exposed to the notion of radicalism that influences behavior, attitudes, and intolerance in religious life (Widyaningsih, Sumiyem, \& Kuntarto, 2017). One of the source of radicalism exposure is books containing the ideology of violence that can easily access via the internet (Iswanto, 2018). 
Religious activities carried out by students tend to turn into intolerant radicalism in religious life (Saifuddin, 2011). Moreover, the increasing of formalism in religious life in the public space lately affected the attitude of radicalism and religious intolerance among students (Muhammad \& Pribadi, 2013) The rise of radicalism among students which has led to religious intolerance is also caused by ideas that contain hatred, hostility, and infidelity to others (Ghifarie, 2016).

Previous studies found some variables that important to enhance religious tolerance, especially in students. The study of Hook et al. (2017) showed that conservatism, religious commitment, humility, and religious intelligence are related to religious tolerance. The more humble the students are, the more tolerant they will be. Another study by Mutsalim \& Jaffary (2014) discovered that students who are inclusive in relationships tend to be more tolerant in their religious life than exclusive students. Whereas Aarøe (2012) explain that the most influential variable on religious tolerance among students is response to the out-groups; the more positive they behave towards the members of the out-group, the more tolerant they become, and vice versa.

Religious orientation is also consider as an important variables determine religious tolerance. Study on religious orientation was started by Allport \& Ross (1967). Allport \& Ross (1967) stated religious orientation is a motivational aspect of religion which divided into two poles, intrinsic and extrinsic orientation person. Person with intrinsic orientation find their master motive in religion, meanwhile person with extrinsic orientation is disposed to use religion for their own ends. Students with intrinsic religious orientation tend to be less aggressive and more tolerant in religious life than extrinsically religious students (Leach, Berman, \& Eubanks, 2008). It shows that the type of religious orientation can affect the religious behavior of the student. Students whose religious orientation is intrinsic tend to have a higher tolerance for diversity compared to students whose religious orientation is extrinsic.

Dudin, Protsenko, Frolova, Voikova, \& Khokonov (2018) stated the most important factor in determining religious tolerance in students is personality factors, such as selfawareness and self-identity. Personality variables such as self-control can affect a student's religious tolerance (Aziz \& Rehman, 1996). The other factors, such as human values that form personality, also affect the religious tolerance of an individual (Hall, Matz, \& Wood, 2010).

Considering the intolerant cases in Indonesia and also previous studies above explained, this study aimed to explore the role of religious orientation and personality on religious tolerance among college students. Religious orientation in this study consists of intrinsic and extrinsic orientation. Whereas the concept of personality traits follows Big Five Personality consisting of five trait namely extraversion, agreeableness, conscientiousness, neuroticism, and openness.

\section{Method}

This study used a quantitative approach with a correlational causality design. Survey methods was used to collect the data by distributing research instruments to participants.

\section{Participants}

Purposive sampling technique was used to select the participant, resulting 280 students of six universities in Surabaya as participants. Table 1 shows the distribution of participants. 
Table 1

Distribution of Respondents

\begin{tabular}{lcc}
\hline Demography & Frequency & Percentage \\
\hline Gender & & 49 \\
Male & 136 & 51 \\
Female & 144 & 50 \\
Religion & & 23 \\
Islam & 141 & 11 \\
Protestant & 64 & 9 \\
Catholic & 31 & 7 \\
Hindus & 26 & 18 \\
Buddhist & & \\
\hline
\end{tabular}

\section{Instrument}

The measurement tools used in this study were three psychological scale, as follows:

(1) Religious Orientation Scale (ROS), this scale measures two types of religious orientation (intrinsic religious orientation and extrinsic religious orientation) compiled based on Religious Orientation Scale-Revised (ROS-R) which has been developed by Gorsuch \& McPherson (Kamaluddin, Nasir, Sulaiman, Khairudin, \& Zamani, 2017). This scale consists of 14 items with good reliability $(\alpha=.912)$.

(2) Personality Scale of Big Five Personality (PS-BFP), this scale measures five personality traits (extraversion, agreeableness, conscientiousness, neuroticism, and openness) adapted from the Big Five Personality Scale (BFPT-S) developed by Hee (2014). PSBFP consists of 44 items and have a good reliability $(\alpha=.943)$.

(3) Scale of Religious Tolerance (S-RT) measures the level of religious tolerance of a person referring to the "A Questionnaire of Religious Tolerance" which has been developed by Al Sadi \& Basit (2013). The SRT consists of 20 items and have a good reliability also $(\alpha=.927)$.

Language and cultural adaptation were carried for all of the research instruments, through the following stages: (1) the translation of the instrument was carried out by two professional translators; (2) the results of the translation were further reviewed by two psychologists; (3) the results of the review by the expert were further used in modify the items; (4) the compiled items were then presented to five lecturers and ten students; (5) the input from readers were used to revise the items; (6) the instrument was tested on fifty students; and (7) selected items are ready to be used as research instruments.

\section{Data analysis}

Multiple linear regressions used to analysis the data. While stepwise technique was used to analysis the effect of each type of religious orientation and personality traits on religious tolerance. All data analysis was conducted with SPSS Program for Windows Version 20.

\section{Results}

Statistical analysis result on Table 2 show that there is a significant simultaneous influence of religious orientations (intrinsic and extrinsic) on religious tolerance among students $(F=$ 28.228; $p=.000)$. Both intrinsic and extrinsic religious orientation have influence on religious tolerance but in different direction. 
Table 2

Multiple regression analysis of religious orientation on religious tolerance

\begin{tabular}{lr}
\hline Statistic & Value \\
\hline$F$ & 28.228 \\
$p$ & .000 \\
$R$ & .411 \\
$R$ square & .169 \\
\hline
\end{tabular}

There is a significant positive influence of intrinsic religious orientation on religious tolerance among students $(\beta=.291 ; t=5.277 ; p=.000)$. It means the higher the students' intrinsic religious orientation, the higher their religious tolerance, and conversely, the lower the students' intrinsic religious orientation, the lower their religious tolerance. On the contrary, there is a significant negative influence of extrinsic religious orientation on religious tolerance among students $(\beta=-.328 ; t=5.951 ; p=.000)$. It can be understood that the higher the students' extrinsic religious orientation, the lower their religious tolerance, and conversely, the lower the students' extrinsic religious orientation, the higher their religious tolerance.

Table 3

Multiple regression analysis of personality trait on religious tolerance

\begin{tabular}{lc}
\hline Statistic & Value \\
\hline$F$ & 6.939 \\
$p$ & .000 \\
$R$ & .335 \\
$R$ square & .112 \\
\hline
\end{tabular}

Table 3 shows there is a simultaneous influence of the personality traits (Big Five Personality) on religious tolerance among college students. Comparing the influence of two variables, religious orientation have a slightly higher influence than personality trait, $16.9 \%$ and $11.2 \%$ respectively.

Table 4

The Influence of Each Personality Trait on Religious Tolerance

\begin{tabular}{lccc}
\hline Personality trait & $B$ & $T$ & $P$ \\
\hline Extraversion & .059 & .856 & .393 \\
Agreeableness & .167 & 2.327 & .021 \\
Conscientiousness & .032 & .474 & .636 \\
Neuroticism & -.047 & -.804 & .422 \\
Openness & .155 & 2.279 & .023 \\
\hline
\end{tabular}

Table 4 shows of the personality traits, only agreeableness personality and openness personality have significant positive influence on religious tolerance. Whereas three other personality traits, that are extraversion personality, conscientiousness personality and neuroticism personality have no significant effect on religious tolerance among college students. 


\section{Discussion}

The results of this study indicated that both religious orientation and personality traits are predictors of religious tolerance among college students. This results in line with a study conducted by Avison \& Furnham (2015) that found two personality traits, agreeableness and extraversion personalities are positively correlated with religious tolerance and religious orientation factors are predictor variables for tolerant behavior in religious life.

Religious orientation significantly influenced religious tolerance among college students. Two types of religious orientation, namely intrinsic religious orientation, and extrinsic religious orientation, differently affected religious tolerance. There was a significant positive influence between intrinsic religious orientation and religious tolerance among students. On the other hand, there was a significant negative effect between extrinsic religious orientation and religious tolerance among students. This finding empirically proved that intrinsically religious college students tended to be more tolerant in their religious life. People with intrinsic religious orientation tend to find out the meaning of their religion and they have more orientation on their belief than on themself. Therefore people with intrinsic orientation openly accept differentiation and more tolerant to other groups.

The results of previous studies also confirmed the influence of religious orientation on religious tolerance. Hosseinkhanzadeh, Yeganeh, \& Mojallal (2013) stated that intrinsic religious orientation positively influences religious attitudes and student self-control. Because intrinsically religious students tend to have more emotional empathy than extrinsically religious students do (Dragun, 2003). Students who are intrinsically religiousoriented tend to have adaptive empathy, and students who are extrinsically religious-oriented tend to be maladaptive (Haneef Khan, Watson, \& Habib, 2005).

On the contrary, college students who were extrinsically religious-oriented tended to be less tolerant in their religious life. People with extrinsic religious orientation tend to use their religion as a way to achieve their goals. Therefore they tend to be communal and use their religion to provide security, comfort, status or social support. Hence people with extrinsic religious orientation consider people from other groups as a threat, so tend to less tolerance.

This study corroborates the opinion of Mora, Stavrinides, \& McDermut (2014) that there is an influence of religious orientation (intrinsic and extrinsic) and personality type on the phenomenon of religious fundamentalism, in which individual who get the more dogmatic in his/her religious, tend to be the more irrational and intolerant in his/her religious life. The study of Duck \& Hunsberger (1999) showed that the higher the students' extrinsic religious orientation, the higher the tendency for prejudice towards other religions, and the higher the students' intrinsic religious orientation, the lower the tendency for prejudice towards other religions. Meanwhile, the results of the study of Wibisono \& Taufik (2017) showed that there is a significant positive correlation between extrinsic religious orientation and religious fundamentalism among students. The higher the students' extrinsic religious orientation, the more radical and lower their religious tolerance.

The results of this study also show that in general, the personality traits measure through Big Five Personality scale, significantly influenced the religious tolerance. The results of this study in line with previous studies that the personality traits influence religious tolerance (Hiebler-Ragger et al., 2018; Oskarsson \& Widmalm, 2016) or intolerant behavior in religious life (Hazel, 2014). While other studies also found that personality traits influence on religious behavior (Abdelsayed, Bustrum, Tisdale, Reimer, \& Camp, 2013), attitudes, feelings, behavior in religious life (Paloutzian, Richardson, \& Rambo, 1999), maturity in 
religious life (Francis \& Pocock, 2009), emotional stability and religiosity of a person (McCullough, Tsang, \& Brion, 2003).

However, partially only agreeableness and openness have significant effect on religious tolerance among college students. This finding corroborates the study of Butrus \& Witenberg (2013) that individuals with conscientiousness and openness personality tend to be more religious tolerance and behaving pro socially. According to Saroglou (2002), someone who has an openness personality tends to be mature in religious life, moderate, open, and deep in spirituality whereas someone who have conscientiousness personality tend to be more mature in the religious life and more tolerant. This study shows that college students with agreeableness and openness personality types tend to be more tolerant in their religion. Students who have the qualities of mutual trust (trust), straightforwardness, altruism, compliance, modesty, and sympathy will influence the patterns of religious behavior that are tolerant, mutual pity, and mutual help to help among religious people. Likewise, students who have properties such as aesthetics, feelings, actions, and ideas, they tend to want peace in their social relationships. Although some previous studies show different results of the influence of each personality type on religious behavior, this study shows that in the context of religious behavior among students, the agreeableness and openness personality types tend to be the strongest influences.

In this study, extraversion personality is not significantly influencing religious tolerance. Previous study found different results on the impact of extraversion personality on religious tolerance. The findings of Aghababaei, Błachnio, Arji, Chiniforoushan, \& Mohammadtabar (2015) showed that extraversion personality has a strong influence on psychological well-being and religiosity of a person so that they are more humanistic in the religious life and able to build harmonious relationships with others (tolerant). However the findings of Gebauer et al. (2014) showed that individual who have neuroticism and extraversion tend to be less religiously tolerant compare to other individual who have three personality traits, agreeableness, conscientiousness, and openness.

However, it is realized that this study contains limitations. Theoretically, this study only includes two personal variables to test their effect on religious tolerance behavior, while external (environmental and social) factors were not included yet. Regarding technical limitations, this study only involved college students in the city of Surabaya with less variations in race, ethnicity, religion, social background. Therefore, further study is needed in order to obtain more comprehensive results on how religious tolerance is influenced by religious orientation and personality types.

\section{Conclusion}

Based on the explanation above, different type of religious orientation have different effect on religious tolerance. Intrinsic religious orientation positively influenced religious tolerance, while extrinsic religious orientation negatively influenced religious tolerance. College students who were intrinsically religious-oriented tended to be more religiously tolerant than who were extrinsically religious-oriented. The personality traits also significantly influenced religious tolerance. However, only agreeableness and openness personalizes partially had a significant effect on religious tolerance among college students. Therefore intrinsic religious orientation, agreeableness and openness personality are needed to increase religious tolerance among college students 


\section{References}

Aarøe, L. (2012). Does tolerance of religion in the public space depend on the salience of the manifestation of religious group membership? Political Behavior, 34(4), 585-606. https://doi.org/10.1007/s11109-011-9179-4

Abdelsayed, L. M., Bustrum, J. M., Tisdale, T. C., Reimer, K. S., \& Camp, C. A. (2013). The impact of personality on God's image, religious coping, and religious motivation among Coptic Orthodox priests. Mental Health, Religion \& Culture, 16(2), 155-172. https://doi.org/10.1080/13674676.2011.652604.

Aghababaei, N., Błachnio, A., Arji, M., Chiniforoushan, M., \& Mohammadtabar, S. (2015). The relations among well-being outcomes, religiosity, and personality. Polish Psychological Bulletin, 46(3), 460-468.

Al Sadi, F. H., \& Basit, T. N. (2013). Religious tolerance in Oman: addressing religious prejudice through educational intervention. British Educational Research Journal, 39(3), 447-472. https://doi.org/10.1080/01411926.2011.652071

Allport, G. W., \& Ross, J. C. (1967). Personal religious orientation and prejudice. Journal of Personality and Social Psychology, 5(4), 432-443. https://doi.org/10.1037/h0021212

Avison, M., \& Furnham, A. (2015). Personality and voluntary childlessness. Journal of Population Research, 32(1), 45-67. https://doi.org/10.1007/s12546-014-9140-6

Aziz, S., \& Rehman, G. (1996). Self control and tolerance among low and high religious groups. Journal of Personality and Clinical Studies, 12(1-2), 83-85.

Bahari, H. (2010). Toleransi beragama mahasiswa: studi tentang pengaruh kepribadian, keterlibatan organisasi, hasil belajar pendidikan agama, dan lingkungan pendidikan terhadap toleransi mahasiswa berbeda agama pada 7 Perguruan Tinggi Umum Negeri) (Religious tolerance among college students: Study on the effect of personality, organisational involvement, religious learning results and educational environment on tolerance among students with different religion in 7 state university). Research report. Jakarta: Badan Litbang dan Diklat Kementrian Agama.

Butrus, N., \& Witenberg, R. T. (2013). Some personality predictors of tolerance to human diversity: The roles of openness, agreeableness, and empathy. Australian Psychologist, 48(4), 290-298. https://doi.org/10.1111/j.1742-9544.2012.00081.x

Byrne, P. (2011). Religious Tolerance, Diversity, and Pluralism. Royal Institute of Philosophy Supplements, 68, 287-309. https://doi.org/10.1017/S1358246111000014

Dragun, A. (2003). Relationships between religious orientation, sexuality and prosociality. Društvena Istraživanja: Časopis Za Opća Društvena Pitanja, 12(1-2), 201-223.

Duck, R. J., \& Hunsberger, B. (1999). Religious orientation and prejudice: The role of religious proscription, right-wing. The International Journal for the Psychology of Religion, 9(3), 157-179. https://doi.org/10.1207/s15327582ijpr0903_1

Dudin, M. N., Protsenko, I. O., Frolova, E. E., Voikova, N. A., \& Khokonov, A. A. (2018). Formation of religious tolerance among undergraduates in the Multireligious Environment of University. European Journal of Science and Theology, 14(2), 77-87.

Francis, L. J., \& Pocock, N. (2009). Personality and religious maturity. Pastoral Psychology, 57(5-6), 235-242. https://doi.org/10.1007/s11089-008-0178-2

Gebauer, J. E., Bleidorn, W., Gosling, S. D., Rentfrow, P. J., Lamb, M. E., \& Potter, J. (2014). Cross-cultural variations in Big Five relationships with religiosity: A sociocultural motives perspective. Journal of Personality and Social Psychology, 107(6), 1064. https://doi.org/10.1037/a0037683

Ghifarie, I. F. (2016). Teologi hakimiyah: Benih radikalisme Islam (Hakimiyah theology: 
The seeds of Islamic radicalism). Islam Realitas: Journal of Islamic \& Social Studies, 2(1), 11-33. https://doi.org/10.30983/islam_realitas.v2i1.96

Hall, D. L., Matz, D. C., \& Wood, W. (2010). Why don't we practice what we preach? A meta-analytic review of religious racism. Personality and Social Psychology Review, 14(1), 126-139. https://doi.org/10.1177/1088868309352179

Handayani, F. (2010). Toleransi beragama dalam perspektif HAM di Indonesia (Religious tolerance in the perspective of human right in Indonesia). Toleransi, 2(1), 62-77.

Haneef Khan, Z., Watson, P. J., \& Habib, F. (2005). Muslim attitudes toward religion, religious orientation and empathy among Pakistanis. Mental Health, Religion \& Culture, 8(1), 49-61. https://doi.org/10.1080/13674670410001666606

Hazel, D. (2014). Relationships of psychological well-being, social morals, and personality among religious and non-religious individuals. Ann Arbor: Fielding Graduate University.

Hee, O. C. (2014). Validity and reliability of the Big Five Personality Traits Scale in Malaysia. International Journal of Innovation and Applied Studies, 5(4), 2028-9324.

Hiebler-Ragger, M., Fuchshuber, J., Dröscher, H., Vajda, C., Fink, A., \& Unterrainer, H. F. (2018). Personality influences the relationship between primary emotions and religious/spiritual well-being. Frontiers in Psychology, 9, 370.

Hook, J. N., Farrell, J. E., Johnson, K. A., Van Tongeren, D. R., Davis, D. E., \& Aten, J. D. (2017). Intellectual humility and religious tolerance. The Journal of Positive Psychology, 12(1), 29-35. https://doi.org/10.3389/fpsyg.2018.00370

Hosseinkhanzadeh, A. A., Yeganeh, T., \& Mojallal, M. (2013). The relationship of the religious orientations and attitudes with self-control among students. Procedia-Social and Behavioral Sciences, 84, 759-762.

Iswanto, A. (2018). Membaca kecenderungan pemikiran Islam generasi milenial Indonesia (Reading the tendency of Islamic thought among Indonesian millenial). Harmoni, 17(1), 172-179. https://doi.org/10.32488/harmoni.v17i1.299

Kamaluddin, M. R., Nasir, R., Sulaiman, W. S. W., Khairudin, R., \& Zamani, Z. A. (2017). Validity and Psychometric Properties of Malay Translated Religious Orientation ScaleRevised among Malaysian Adult Samples (Kesahan dan Sifat-Sifat Psikometrik Skala Orientasi Keagamaan-Semakan yang diterjemahkan dalam Bahasa Malaysia dalam Kalangan Sampe. Akademika, 87(2), 133-144. https://doi.org/10.17576/akad-20178702-10

Leach, M. M., Berman, M. E., \& Eubanks, L. (2008). Religious activities, religious orientation, and aggressive behavior. Journal for the Scientific Study of Religion, 47(2), 311-319. https://doi.org/10.1111/j.1468-5906.2008.00409.x

McCullough, M. E., Tsang, J.-A., \& Brion, S. (2003). Personality traits in adolescence as predictors of religiousness in early adulthood: Findings from the Terman Longitudinal Study. Personality and Social Psychology Bulletin, 29(8), 980-991. https://doi.org/10.1177/0146167203253210

Mora, L. E., Stavrinides, P., \& McDermut, W. (2014). Religious fundamentalism and religious orientation among the Greek orthodox. Journal of Religion and Health, 53(5), 1498-1513. https://doi.org/10.1007/s10943-013-9734-x

Muhammad, W. A., \& Pribadi, K. K. (2013). Anak muda, radikalisme, dan budaya populer (Youth, radicalism, and popular culture). Jurnal Maarif, 8(1), 132-153.

Mutsalim, K., \& Jaffary, A. (2014). Toleransi beragama \& implikasinya dalam kalangan mahasiswa/i Muslim dan Buddha di Prince of Songkhla University. Thailand.[The Religious Tolerance and the Implication between Muslim/Buddha Student in Prince of Songhla University, Thailand]. Journal of Islamic and Arabic Education, 5, 1-14. 
Oskarsson, S., \& Widmalm, S. (2016). Personality and political tolerance: Evidence from India and Pakistan. Political Studies, 64(1), 235-254. https://doi.org/10.1111/14679248.12169

Paloutzian, R. F., Richardson, J. T., \& Rambo, L. R. (1999). Religious conversion and personality change. Journal of Personality, 67(6), 1047-1079. https://doi.org/10.1111/1467-6494.00082

Saifuddin, S. (2011). Radikalisme Islam di kalangan mahasiswa: Sebuah metamorfosa baru (Islamic radicalism among college students: A new metamorphosis). Analisis: Jurnal Studi Keislaman, 11(1), 17-32.

Saroglou, V. (2002). Religion and the five factors of personality: A meta-analytic review. Personality and Individual Differences, 32(1), 15-25. https://doi.org/10.1016/S01918869(00)00233-6

Wibisono, S., \& Taufik, M. (2017). Orientasi keberagamaan ekstrinsik dan fundamentalisme agama pada mahasiswa Muslim: Analisis dengan model Rasch (Extrinsic religious orientation and religious fundamentaliam among Muslim college students: Rasch model analysis). Jurnal Psikologi Sosial, 15(1), 1-11. https://doi.org/10.7454/jps.2017.1

Widyaningsih, R., Sumiyem, S., \& Kuntarto, K. (2017). Kerentanan radikalisme agama di kalangan anak muda (Vulnerability of radicalism among youth). Journal LPPM, 7(1), $1553-1562$. 